\title{
Long Run Determinants of Private Consumption Spending: Evidence from Nigeria
}

\author{
Joseph Chukwudi Odionye ${ }^{1}$, Okanta Sunday Ukeje ${ }^{2}$ \\ ${ }^{1}$ Department of Economics, Faculty of Business Administration, AbiaState University, Uturu, Nigeria \\ ${ }^{2}$ Department of Banking and Finance, Faculty of Business Administration, AbiaState University, Uturu, Nigeria
}

Email address:

josephodionye $a$ yahoo.com (J. C. Odionye), sundayokanta $a$ yahoo.com (O. S. Ukeje)

\section{To cite this article:}

Joseph Chukwudi Odionye, Okanta Sunday Ukeje. Long Run Determinants of Private Consumption Spending: Evidence from Nigeria. Journal of Business and Economic Development. Vol. 4, No. 1, 2019, pp. 23-30. doi: 10.11648/j.jbed.20190401.14

Received: January 8, 2019; Accepted: February 22, 2019; Published: May 20, 2019

\begin{abstract}
Of great concern to policy makers and researchers are the factors that influence private consumption spending owing to the important role it plays in aggregate demand of a country. Thus, this study investigated the long run determinants of aggregate private consumption spending in Nigeriaover thequarterlyperiodsof 1981 to 2016. The Auto Regressive Distributed Lag Error-correction model (ARDL-ECM) was employed to take care of short-run dynamics. In line with theories, variables included in the model were disposable income, credit facility, financial assets, government expenditure, interest rate and inflation rate. The empirical results showed that in the short run, disposable income, financial assets, interest rate and government expenditure influence private consumption spending while disposable income, financial assets, credit facilities and government expenditures are the major long run determinants of private consumption spending in Nigeria. The result equally showed that disposable income has more impact on consumption spending in the long run than it has in the short run. The policy implication is that policy interventions directed towards these variables are essential to increase spending as a major component of aggregate demand.
\end{abstract}

Keywords: Private Consumption, ARDL, Financial Assets, ECM, Credit Facility

\section{Introduction}

Factors influencing consumption spending have been of great concern to researchers and policy makers both within the advanced and growing nations as it represents a main financial idea featured prominently in the literatures of both micro and macroeconomic theories. It has consequently become the focal point of most insightful empirical paintings in macroeconomics over the last three decades. Consumption represents the most important component of aggregate demand in Nigeria.

Theoretical, there are conflicting views on determinants of consumption spending. Following the classical works of Keynes, the most critical aspect influencing the quantity of purchaser spending is the extent of disposable income [1]. As earnings rises, patron spending will increase proportionally, but by means of a fraction of the preliminary growth in earnings. Though consumption spending is decided ordinarily by using the level of disposable income, consumers as a way to maximize utility goals to smooth intake over time, they may cut links between consumption and some other variable together with income. In order to do this, consumers will look to their lengthy-time period income prospect and regulate consumption to it instead of real income. In this case, non-earnings elements also play a function. Those non-income elements include human beings' expectations about what will appear to prices and to their earning, the cost and availability of customer credit, and the general wealth of customers. In economic literature, both the Permanent Income Hypothesis and the Life-Cycle Speculation state that family wealth is a key detail for determining consumption spending [2-3]. In keeping with these fashions, non-public consumption is a function of human wealth, measured because the modern cost of anticipated lifetime profits, and of financial wealth, similar to the stock of assets held via households and the corresponding income. Purchasers consequently tend to easy consumption by taking predicted earnings into account; they borrow even as they are young, keep at some stage in their running 
existence and devour amassed savings throughout retirement. Any unanticipated rise in (human and economic) wealth is distributed over the remaining lifetime, elevating now not best modern consumption however additionally future intake, the goal being to hold an incredibly strong pattern through the years [4].

These theoretical conflicts have brought about many researches on the determinants of consumptions spending in both advanced and developing countries but the empirical outcomes are mixed relying on the methodology [5-6]. This observe differed from previous research by means of using Auto-Regressive Distributive Lag (ARDL) cointegration check in a quarterly series from 1981 to 2015 .

The level of spending on intake in a country depicts the total demand for items and service in that country and in maximum cases in growing economic system including Nigeria; it constitutes about 60 percent of the overall GDP of the country. Consumption spending also depicts the extent of welfare and poverty that a nation is experiencing. Consumption spending is consequently a higher indicator of living standards [7]. It is far well worth noting that after a rustic's financial system is experiencing a downturn fashion, it means that the aggregate demand (consumption spending) is in decline, poverty prevalence is on the growth, unemployment rate rises, and investments fall notably and fees of goods and services maximum in all likelihood upward thrust too. Then again, while the aggregate demand (consumption spending) is excessive, firms will invest and be geared up to employ idle sources, costs will fall (because of increase in the supply of goods and services) and other economies of scale may be gathered to the country because of the massive size of its total demand [8].

Consumption spending may be very important in improving the GDP of a nation. This can be viable through the impact it has on investment. If goods manufactured inside the economic system are patronized via customers, producer's income will increase, and this may enable them to reinforce their funding and as a result improve the level of employment. During times when there is low intake of goods and services (recession) production activities are very slow and investments are hampered. Any alternate in aggregate demand causes a change in income, and a change in income causes an alternate in consumption. No matter the good sized growth in financial boom that the economy has skilled in recent years, the economic system continues experiencing high unemployment, rising poverty degree and earnings inequality. In line with data from national bureau of statistics, unemployment rate has been on the boom and in a geometric trend because it rose from 11.9 percent in 2005 to 19.7 percent in 2009 and 24.3 percent in 2012. Absolute poverty nonetheless stays sizeable at 60.9 percent in 2010 from 50.7 percent in 2004, and then income inequality rose from 0.43 in 2004 to 0.49 in 2009 . The hallmark of poverty in Nigeria is the excessive stage of unemployment. Unemployment economically translates to low purchasing power which finally results in a lower intake spending [7].

It is against this heritage that the study of the determinants of consumption is very crucial in Nigeria. This takes a look at is paramount more so due to the peculiarity of the intake sample in Nigeria. The family final consumption expenditure as a percentage of GDPin Nigeria is $61.29 \%, 59.66 \%$, $66.67 \%, 68.18 \%, 75.2 \%, 65.2 \%, 77.56 \%, 63.25 \%, 75.16 \%$, $73.56 \%, 80.58 \%$ and $77.22 \%$ for the years $2013,2012,2011$, 2010, 2009, 2008, 2007, 2006, 2005, 2004, 2003 and 2002 respectively. In the case of the annual growth rate of GDP, the report has it that the figures have also been fluctuating within these periods. In 2013, 2012, 2011, 2010, 2009, 2008, 2007, 2006, 2005, 2004, 2003 and 2002, the figures are as follows: $4.4 \%, 3.8 \%, 1.8 \%, 4.9 \%, 4.06 \%, 3.4 \%, 4.02 \%$, $5.3 \%, 0.78 \%, 30.3 \%, 7.6 \%$ and $1.19 \%$ respectively [9].

As a result, if you want to raise consumption spending, it is far critical to decide the long term determinants of consumption spending in Nigeria. This work is organized into five sections; following the introductory section is section two which explored the existing literature. Section three examined the data and methodological issues. While section four discussed the empirical results, section five is conclusion and policy implications.

\section{Literature Review}

There are diverse theories in economic literature regarding factors that influence consumption spending. Notable amongst them are the Absolute Income Hypothesis, the Duesenberry's Relative Income Hypothesis, the Friedman's Permanent Income Hypothesis and Ando and Modigliani Life Cycle Hypothesis [1-2].

\subsection{Theoretical Literature}

\subsubsection{Absolute Income Hypothesis (AIH)}

The aggregate consumption function is a center element inside the Keynesian theory of income dedication. Within the general concept Keynes gave primary significance to disposal income as the leader determinant of aggregate consumption. Keynes is mentioned as the first to postulate the principle of consumption popularly called absolute income hypothesis (AIH), wherein he worked on the connection on earnings and consumption and got here out with the finding that income is the only determinant of consumption. Consistent with Keynes, consumption comply with the essential mental law. The fundamental mental law upon which we are entitled to depend with first-rate self belief as a priori from our facts of experience is that guys are disposed, in general at the average to increase their intake as their earnings increases, but not as much as the extended income [1]. In different phrases, as the extent of income in the economy will increase less of the increased income is consumed, whilst savings increases.

\subsubsection{Relative Income Hypothesis (RIH)}

In assessment to Keynes' argument, Duesenberry's Relative income hypothesis (RIH) asserts that; (1) every character's consumption conduct is not independent but interdependent of the behaviour of every other man or 
woman; and a pair of and (2) intake family members are irreversible and now not reversible in time. In formulating his principle of consumption function, Duesenberry states that "actual understanding of the problem of purchaser behavior must begin with a complete recognition of the social charater of consumption patterns." Through the "social character of intake styles" he approaches the tendency in humans not only "to hold up with joneses" but additionally to surpass the joneses. In other words, the tendency is to try constantly closer to a higher consumption level and to emulate the consumption patterns of one's wealthy neighbor and companion. For that reason consumers' choices are interdependent. It is, but, differences in relative incomes that decide the consumption expenditure in a network. A rich man or woman could have a lower APC (average propensity to consume) because he is going to need a small portion of his income to maintain his consumption pattern. Alternatively, a relatively poor man may have a higher APC due to the fact he tries to hold up with the intake standards of his neighbors or friends.

\subsubsection{Permanent Income Hypothesis (PIH)}

Another solution to the obvious contradiction between the proportional long-run and non proportional short-run intake feature is the Friedman's permanent income speculation. Friedman rejects the usage of current income as the determinant of intake expenditure and alternatively divides both consumption and income into permanent and transitory additives in order that

$\mathrm{Y}=\mathrm{Yp}+\mathrm{Yt}$ and $\mathrm{C}=\mathrm{Cp}+\mathrm{Ct}$ in which $\mathrm{p}$ refers to permanent and $\mathrm{t}$ refers to transitory earnings $\mathrm{Y}$ and consumption C. Permanent income is described as "the quantity a purchaser unit should eat whilst maintaining its wealth intact." it is the principle income of a family unit which in turn rely on its time horizon and farsightedness. It consists of non human wealth that it owns, the non-public characteristic of earners inside the unit and the attributes of the economic hobby of the earners, along with career accompanied the location of monetary pastime and so forth. $\mathrm{Y}$ being the purchaser measured income or current income; it may be larger or smaller than his permanent income in any length. Such differences between measured and permanent income are because of transitory element of income (Yt). Transitory income may also move upward or downward with providence gains or losses and cyclical variations. If the transitory income is high quality due to a windfall advantage, the measured earnings will rise above permanent earnings. If the transitory earnings is negative because of robbery, the measured earnings fall below the permanent earnings. The transitory income can also be zero wherein case measured income equals everlasting earnings.

\subsubsection{Life Cycle Hypothesis ( $\mathrm{LCH}$ )}

Ando and Modigliani have formulated a consumption characteristic that is known as the Life Cycle hypothesis. According to this idea, consumption is a feature of lifetime expected income of the customer. The consumption of the character purchaser depends on the resources available to him, the rate of return on capital, the spending plan and the age at which the plan is made. The present cost of his income (or resources) includes profits from assets or belongings and from modern and expected labour income.

Its assumption is based on: there may be no change in the price level all through the life of the consumer, the rate of interest remains solid, the consumer does not inherit any property and his net assets are the end result of his own savings. The intention of the purchaser is to maximize his utility over his lifetime which in turn depends on the full assets available to him throughout his lifetime. Given the life span of a person, his intake is proportional to those sources. However the proportion of the sources that the patron plans to spend will depend on whether or not the spending plan is formulated in the course of the early or later years of his life. Generally, a person common income is pretty low at the start of his lifestyles and additionally at the end of his existence. That is because in the beginning of his life he has little property, and in the course of the late years his labour income is low. It is far, but, within the center of his lifestyles that his income, each from property and labour is high. As a result, the intake level of the person for the duration of his life is really constant or barely increasing.

\subsection{Empirical Literature}

One of the previous studies carried out on the household welfare effect of macroeconomic volatility on private consumption expenditure (PCE) in Nigeria employed Structural Vector Auto-Regression (SVAR) model. Variables included in the model were PCE, real exchange rate, general price level (inflation rate), unemployment rate and debt service ratio, for the period 1980-2008 [10]. The model ascertained the extent in which volatility of the macroeconomics does lead to a decline in consumption expenditure. They found that, the PCE response to structural one innovation appears to be greater in inflation than other endogenous variables. Also, inflation innovations play a larger role in explaining PCE forecast error variance in the long run than they do in the short run and this generates negative net effects on welfare.

In another related study, carried out the researcher estimated the Nigeria ' $\mathrm{s}$ marginal propensity to consume (MPC) within the period 1980 - 2004. The econometrics methodology of unit root, and co integration were used to determine the stationary and the long run relationship among the variables. The computation of MPC and APC were carried out using the nominal data obtained from the identified variables. They found that MPC and APC conform to Keynes proposition that is less than one and stable [11]. The researcher argued that the finding has serious policy implications for saving, capital formation, and investment on whole. The author therefore suggest for a policy to discourage consumption and encourage production.

Investigating the impact of change in gross domestic product (income) on private consumption expenditure in Nigeria from 1981 to 2010, the researcher employedthe classical (OLS) simple regression analysis to examine the 
impact of gross domestic product on consumption expenditure and to determine the order of integration of consumption expenditure and gross domestic product. Their results show a positive significant impact of Gross Domestic Product (income) on Private Consumption Expenditure with a slope of 0.6708253 . The unit root test (order of stationary) also shows a non existence of unit root at their level. The pvalue and the coefficient of determination ( $\mathrm{R} 2=.9838)$, implies that gross domestic product explains $98.4 \%$ of private consumption expenditure [12]. Hence, their findings reveal a significant relationship between gross domestic product and private consumption expenditure.

The examination of the determinants of aggregate consumption expenditure in Nigeria was carried out, with the help of Ordinary Least Square (OLS) technique. The study found a positive relationship between consumption expenditure and income [6]. This study proved that the Nigeria consumption function conforms to Keynesian consumption model and also incorporates the idea of other well known theories as, interest rate; price level and exchange rate were significant variables explaining consumption behaviour in Nigeria. Policies to combat inflation, employment creation to increase purchasing power in the hands of more Nigerians and a check on the continuous depreciation of the naira were suggested recommendations.

In a more related and recent study, investigated the effects of financial wealth on private consumption in Nigeria was examined. The study employed ordinary least square (OLS) technique in analyzing annual data sourced from CBN bulletin from 1981 to 2015 [5]. Thefinding of the work showed that both disposable income and financial wealth have positive effects on private consumption. But only disposable income has significant effect while financial wealth has insignificant effect on private consumption.

\section{Data and Methodological Issues}

Given that this study aimed at finding out the long run determinants of consumption spending in Nigeria, ARDL model was employed. The functional form is given as

$$
\mathrm{CONS}=\mathrm{f}(\mathrm{DINC}, \mathrm{CRD}, \mathrm{FNAS}, \mathrm{GEX}, \mathrm{INT}, \mathrm{INF})
$$

Where, CONS = Aggregate consumption spending, DINC $=$ disposable income, FNAS $=$ financial asset used as proxy for wealth, $\mathrm{CRD}=$ credit facility, GEX $=$ total government expenditure used as proxy for fiscal policy, INT = interest rate and $\mathrm{INF}=$ inflation rate.

The choice of ARDL model was based on its advantages over other models. The Auto Regressive Distributed Lag (ARDL) Model which uses a bounds test approach based on unrestricted error correction model (UECM) was employed here to determine the long run determinants of consumption spending. This model, as developed by Pesaran and Pesaran, has been widely used to analyze a long run relationship between variables because of its advantages over other cointegration models. One of advantages of this model is that it can be applied irrespective of whether the variables are I (0) or I (1). This approach also allows for the model to take a sufficient number lags to capture the data generating process in a general-to-specific modelling framework [13-14]. Although, a dynamic error correction model (ECM) can be derived from ARDL through a simple linear transformation, bound testing is an alternative model to test for the existence of cointegration among the variables [13]. The bounds test procedure is merely based on an estimate of unrestricted error correction model (UECM) using ordinary least squares estimator.

Following economic literature and some previous works, the ARDL model is given in the equation below [16 and 17]

$$
\begin{aligned}
& \operatorname{CONS}_{t}=\alpha_{0}+\sum_{i=1}^{p} \gamma_{i} \operatorname{CONS}_{t-i}+\sum_{i=0}^{p} \beta_{i} D I N C_{t-i}+\sum_{i=0}^{p} \beta_{i} F N A S_{t-i}+\sum_{i=0}^{p} \beta_{i} I N T_{t-i}+ \\
& \sum_{i=0}^{p} \beta_{i} G E X_{t-i}+\sum_{i=0}^{p} \beta_{i} C R D_{t-i}+\sum_{i=0}^{p} \beta_{i} I N F_{t-i}+\mu_{i t}
\end{aligned}
$$

In order to obtain the cointegrating equation, equation 2 is transformed into 3 as follows:

$$
\begin{aligned}
& \Delta \text { CONS }_{t}=\alpha_{0}+\sum_{i=1}^{p} \gamma_{i} \Delta C O N S_{t-i}+\sum_{i=0}^{p} \beta_{i} \Delta D I N C_{t-i}+\sum_{i=0}^{p} \beta_{i} \Delta F N A S_{t-i}+\sum_{i=0}^{p} \beta_{i} \Delta I N T_{t-i}+ \\
& \sum_{i=0}^{p} \beta_{i} \Delta G E X_{t-i}+\sum_{i=0}^{p} \beta_{i} \Delta C R D_{t-i}+\sum_{i=0}^{p} \beta_{i} \Delta I N F_{t-i}-\phi E C T_{t-1}+\mu_{i t} \\
& \text { Where } E C T_{t}=Y_{t}-\alpha_{0}-\sum_{i=1}^{p} \gamma_{1} \Delta Y_{t-i}-\sum_{i=0}^{p} \beta_{i} \Delta X_{t-i} \text { and } \phi=1-\sum_{i=1}^{p} \gamma_{1} \Delta Y_{t-i} .
\end{aligned}
$$

The Bound test procedure used equations 3 and 4 into 5 as:

$$
\Delta Y_{t}=-\sum_{i=1}^{p-1} \gamma_{1} Y * \Delta Y_{t-i}+\sum_{i=0}^{p} \beta_{i} \Delta X_{t-i}-\rho Y_{t-1}-\alpha-\sum_{i=0}^{p} \delta X_{t-i}+\mu_{i t}
$$

Then we test the existence of level relationship as $\rho=0$ and $\delta_{1}=\delta_{2}=\ldots=\delta_{\mathrm{k}}=0$ where $\Delta=$ difference operator, $\mu=$ white noise error term.

The terms with the summation signs in equation 3 
represent the Error Correction Model (ECM) dynamics and the coefficients $\beta_{i}$ are the long run multipliers corresponding to long run relationship. $\beta_{i}$ and $\mu$ represent the constant and the white noise respectively. $\Delta$ is the first difference operator. The data used for this study are secondary quarterly data and were sourced from Central Bank of Nigeria, covering the period of $1981-2015$ [18].

\subsection{Unit Root Tests}

It is important to check each time series variable for stationarity or unit root before conducting the co-integration test on specified models. The unit root test has to be conducted first because without it, if the regression analysis is conducted in the traditional way and time series variables are found to be non-stationary, the result will be spurious. Here we use the Augmented Dickey Fuller (ADF) for the unit root tests.

The ADF is unit root test for time series. It is shown in the equation below:

$$
\Delta Y_{t}=\beta_{0}+\beta_{1} \mathrm{t}+\delta Y_{t-1}+\sum_{i=1}^{n} \alpha_{i} \Delta Y_{t-i}+\varepsilon_{t}
$$

where $Y_{t}$ is the variable in question, $\varepsilon_{t}$ is white noise error term.

These tests are used to determine whether the estimated $\delta$ is equal to zero or not. The number of lagged difference terms to include is often determined empirically, the idea being to include enough terms so that the error term in (6) is serially uncorrelated. The idea is to compile cumulative distribution of the ADF statistics by showing that if the value of the calculated ratio of the coefficient is less than critical value from $\mathrm{ADF}$ statistics, then $\mathrm{Y}$ is said to be stationary.

\subsection{Co-integration Test}

The bound co-integration test was employed in this study to test for the existence of long-run determinants of consumption. The choice of this test was based on its advantages over other cointegration tests [see 13-14]. The test involves asymptotic critical bounds depending on whether the variables are 1(0) or 1(1) or a mixture of the both. Two sets of critical values are generated, with one set refers to as the 1(1) series and the other the 1(0) series. Critical values for the 1(1) series are referred to as the upper bound critical values while that of the 1(0) series are referred to as the lower bound series. If the $F$ test statistics exceed their expected critical values we can conclude that there is evidence of long-run relationship between the variable irrespective of their order of integration and vice versa [14].

\section{Empirical Result and Discussion}

\subsection{Unit Root Test}

A unit root test (ADF) was conducted to ascertain whether the variables in the model are stationary and to determine the order of integration of the model variables. This is necessary as it helps to avoid spurious regression results.

The summary of Unit Root Tests (ADF) results using Eviews software is detailed in the table below:

Table 1. Summary of ADF test results at $1 \%, 5 \%$ and $10 \%$ critical value.

\begin{tabular}{|c|c|c|c|c|c|c|c|}
\hline \multirow{2}{*}{ Variable } & \multirow{2}{*}{ Order of Integration } & \multirow{2}{*}{ ADF Test Statistics } & \multicolumn{3}{|c|}{ ADF Critical Value } & \multirow{2}{*}{ Lag Length } & \multirow{2}{*}{ Remark } \\
\hline & & & $1 \%$ & $5 \%$ & $10 \%$ & & \\
\hline CONS & $\mathrm{I} \sim(0)$ & -3.288 & -3.283 & -2.885 & -2.579 & 10 & Stationary \\
\hline DINC & $\mathrm{I} \sim(1)$ & -2.184 & -2.584 & -1.943 & -1.615 & 11 & Stationary \\
\hline FNAS & $\mathrm{I} \sim(1)$ & -5.092 & -4.033 & -3.446 & -3.148 & 9 & Stationary \\
\hline GEX & $\mathrm{I} \sim(1)$ & -9.451 & -3.480 & -2.883 & -2.579 & 2 & Stationary \\
\hline CRD & $\mathrm{I} \sim(1)$ & -2.576 & -2.584 & -1.943 & -1.615 & 11 & Stationary \\
\hline INF & $\mathrm{I} \sim(1)$ & -4.981 & -3.483 & -2.884 & -2.579 & 8 & Stationary \\
\hline INT & $\mathrm{I} \sim(1)$ & -13.026 & -3.480 & -2.883 & -2.579 & 1 & Stationary \\
\hline
\end{tabular}

From table 1, observe that the variables DINC, FNAS, GEX, CRD, INF and INT are not stationary at level form but became stationary after first difference which implies that the variables are integrated of orderone $(\mathrm{I} \sim(1))$ whereas the variable $(\mathrm{CONS})$ is integrated of order zero $(\mathrm{I} \sim(0))$ as it is stationary at level form. The decision is based on the fact the $\mathrm{ADF}$ statistics is greater than the ADF critical values at $5 \%$ and $10 \%$ level. Thus, we reject $\mathrm{H}_{0}$ and conclude that the variable is stationary.

Since the variables are integrated of order one and zero and none of the variables is integrated of order two. We therefore, apply the ARDL bound cointegration test. But before we apply the ARDL bound cointegration test, we first determine the optimum lag length using Akaike information criteria. After twenty (20) models automatically generated, ARDL $(3,4,4,1,1,0,0)$ model was chosen based on Akaike information criteria to determine the factors that influence consumption expenditure (see appendix).

\subsection{ARDL Bound Cointegration Test}

A necessary condition for testing for ARDL bound cointegrating test is that each of the variables be integrated of either of order one or zero or both [14]. Since all the variables are integrated of order one and zero, we proceeded to estimate the ARDL bound test. The null hypothesis of ARDL bound cointegration is that the variables are not cointegrated as against the alternative that they are cointegrated. The decision rule is to reject the null hypothesis if the F-statistics is greater than the upper bound critical values at 5\% level of significance. The result of the ARDL cointegration test for the first and second objectives is shown 
in table 2 below.

Table 2. ARDL Bound Cointegration Test Result for Objectives 1 and 2.

\begin{tabular}{llllll}
\hline \multirow{2}{*}{ Model } & \multirow{2}{*}{ F-Statistics } & \multirow{2}{*}{ K } & Significance level & Critical Bound Value & \\
\cline { 4 - 5 } & & $5 \%$ & $\mathbf{1 0}$ (Lower Bound) & 11 (Upper Bound) \\
\hline \multirow{2}{*}{4.276969} & & $1 \%$ & 3.45 & 3.61 \\
& & & 3.15 & 4.43 \\
\hline
\end{tabular}

From table 2 the F-statistics of 4.277 is greater than the upper (I1) bound of 3.61 at 5\% level of significance. Thus, we reject the null hypothesis and conclude that there is cointegration in the model. This implies that there is a long run relationship between consumption spending and its determinants in Nigeria. We therefore estimate the short run and long run ARDL regression model and the results are presented in tables 3 and 4 below respectively:

Table 3. Summary of Parsimonious Short Run Determinants of Consumption Result

ARDL Model (3, 4, 4, 1, 1, 0, 0,)

\begin{tabular}{|c|c|c|c|c|}
\hline \multirow{2}{*}{ Variables } & \multicolumn{4}{|c|}{ Dependent Variable CONS } \\
\hline & Coefficient & Std. Error & t-statistics & Probability \\
\hline Constant & $2.972 .510 * * *$ & 879.0013 & 3.381690 & 0.0010 \\
\hline CONS(-1) & $0.192536 * *$ & 0.090525 & 2.126884 & 0.0356 \\
\hline CONS(-2) & $0.389149 * * *$ & 0.087247 & 4.460332 & 0.0000 \\
\hline CONS(-3) & $0.533749 * * *$ & 0.101933 & 5.236249 & 0.0000 \\
\hline $\mathrm{D}(\mathrm{CRD})$ & $0.251517 * *$ & 0.109303 & 2.301096 & 0.0232 \\
\hline $\mathrm{D}(\mathrm{CRD}(-4))$ & $0.327346^{* * *}$ & 0.111797 & 2.928036 & 0.0041 \\
\hline D(DINC(-2)) & $0.188121 * * *$ & 0.046113 & 4.079605 & 0.0001 \\
\hline $\mathrm{D}(\mathrm{DINC}(-3))$ & $0.267270 * * *$ & 0.055847 & 4.785793 & 0.0000 \\
\hline D(DINC(-4)) & $0.193010^{* * *}$ & 0.048939 & 3.943931 & 0.0001 \\
\hline D(FNAS(-1)) & $-0.848927 * * *$ & 0.275142 & -3.085420 & 0.0026 \\
\hline $\mathrm{D}(\mathrm{GEX})$ & $0.608777 * * *$ & 0.185874 & 3.275212 & 0.0014 \\
\hline $\mathrm{D}(\operatorname{GEX}(-1))$ & $0.783585 * * *$ & 0.271969 & 2.881156 & 0.0047 \\
\hline D(INF) & -7.026184 & 3.968999 & -1.770266 & 0.0794 \\
\hline \multicolumn{5}{|c|}{ R-squared $=0.993244$} \\
\hline \multicolumn{5}{|c|}{ Adj R-Squared $=0.997098$} \\
\hline \multicolumn{5}{|c|}{ F-Statistics $=866.63 \mathrm{~F}-$ prob $=0.0000$} \\
\hline
\end{tabular}

$* * *[* *]$ denotes significant of variable at $1 \%[5 \%]$ significance level respectively.

\subsection{Interpretation of Short Run ARDL Result}

From table 3, the constant value is 2972.51 , meaning that when other variables that determine consumption is zero, the aggregate consumption will 2972.51 and it is statistically significant. This is in line with theory explaining the autonomous consumption in the model.

The coefficients of the previous values of consumption up to lag three (3) are positive and statistically significant implying that the present consumption level is determined by the previous consumption levels of the first three periods. The coefficients of disposable income (DINC) up to lag four (4) are positive and statistically significant implying that it has a positive impact on aggregate consumption in Nigeria. This further suggests specifically that a 1 naira increase in current year disposable income will increase consumption by 0.47 naira while disposable income at lag two, three and four will increase consumption by $0.19,0.27$ and 0.19 naira respectively. This implies that a unit increase in disposable income will have more impact on consumption in the current year than in the previous values. This result is consistent with economic 'a priori' expectation validating the Keynesian consumption theory which says that 'men on average tend to increase consumption as income increases but not as much as increase in income $(0<\mathrm{MPC}<1)$. This result corroborates the findings of Bimal and Sakib [19-20].

The coefficient of financial assets (FNAS) at lag one is 0.849 , implying that a unit increase in financial assets will reduce consumption level by 0.849 units. This can be explained on the ground that acquisition of financial assets requires savings and savings means sacrificing immediate consumption and this, in turn, will lead to a decrease in consumption level. This result supports the finding of Richardo and Bimal [21, 19]. The coefficients of government expenditure (GEX) are positive for both at current year and at immediate previous period in the short run. This implies that increase in government expenditure will increase consumption through increase in income. This is consistent with economic theory.

Credit facilities (CRD) for both current period and four period lag have positive impact on consumption in the short run. Specifically, one naira increase in credit facilities at current and previous values will increase consumption level by 0.25 and 0.33 respectively. Increase in credit facilities will increase consumption through increase in income occasioned by increase in investment. This is consistent with economic theory that 
increase in credit facilities will enable households to have more access to credit and this in turn will increase investment and income and hence consumption level will increase.

Inflation rate coefficient is -7.02 suggesting that a one unit increase in inflation will reduce consumption level by 7.02 levels. The implication of this result is that consumers will tend to consume more when the general price level falls that when it rises. This is in line with theory as people's real income will be badly (negatively) affected during inflation and hence a decrease in consumption level. This result corroborates the findings of Kandil and Mirzaie [22]. The coefficient of interest rate is 34.02 suggesting that increase in interest rate will lead to increase in consumption. This results in inconsistent with economic theory.

The coefficient of error correction model (ECM (-1)) is ($0.215)$ and is appropriately signed. This speed of adjustment suggests that about $21.5 \%$ of the previous period's disequilibrium in consumption function is corrected every quarter by its determinants. The implication is that it will take five quarters (two years and quarter) for any disequilibrium in the consumption to be corrected. The coefficients of multiple determinations and its adjusted are 0.993 and 0.992 respectively, suggesting that about $99.3 \%$ of the variations in consumption is explained by the variables included in the model. This further shows a good explanatory power of the model.

Table 4. Summary of Long Run Determinants of Consumption Result.

\begin{tabular}{llll}
\hline \multirow{2}{*}{ Variables } & \multicolumn{2}{l}{ Dependent Variable CONS } & t-statistics \\
\cline { 2 - 4 } & Coefficient & Std. Error & -4.609539 \\
\hline CREDT(-1) & $-0.545437 * * *$ & 0.118328 & 7.266709 \\
DISY(-1) & $2.460112^{* * *}$ & 0.338546 & 4.172659 \\
DISY(-2) & $2.296209^{* * *}$ & 0.550299 & 6.321910 \\
FINASS(-1) & $1.567552^{* * *}$ & 0.247955 & 5.707402 \\
GEX(-1) & $1.495932 * * *$ & 2.262104 & -0.363197 \\
INFL(-1) & -4.961493 & 13.66063 & 0.0000 \\
INTR & 32.88056 & 35.79883 & 0.918481 \\
\hline
\end{tabular}

$* * *[* *]$ denotes significant of variable at $1 \%[5 \%]$ significance level respectively.

Table 5. Results of Diagnostic Tests.

\begin{tabular}{lll}
\hline & X $^{\mathbf{2} \text { Statistics }}$ & Probability \\
\hline Breusch-Godfrey LM test for autocorrelation & 2.144 & 0.1528 \\
White Heteroskedasticity & 1.064 & 0.429 \\
Normality Text (J. B) & 0.368 & 0.831 \\
Ramsey RESET Test & 3.32 & 0.0739 \\
\hline
\end{tabular}

\subsection{Interpretation of Long Run ARDL Result}

From table 4, the coefficients of disposable income (DINC) up to lag two (2) are positively and statistically significant implying that it has a positive impact on aggregate consumption in the long run in Nigeria. This further suggests specifically that a 1 naira increase in disposable income at lag one and two will increase consumption by 2.46 and 2.29 naira respectively. The long run coefficients of disposable income suggest that in the long run men on the average will tend to spend more than the increase in their disposable income. This is in line with theory which explains that the Keynesian consumption theory is only in the short run because in the long, other factors like financial wealth, assets, etc, will influence people level of consumption. This result corroborates the findings of Bimal and Sakib [19, 20].

The long run coefficient of financial assets (FNAS) at lag one is 1.56755 , implying that a unit increase in financial assets will increase consumption level by 1.57 units in the long run. This implies that in the long run financial assets will start to yield returns which will further increase income and in return, it will increase consumption. This result validates the Permanent Income Hypothesis, and Life Cycle Hypothesis which stated that a financial asset is a major determinant of private consumption [2-3]. This result corroborates the findings of Odionye et al [5].

The coefficient of government expenditure (GEX) is positive at lag one in the long run. This implies that increase in government expenditure will increase consumption through increase in income. This is consistent with economic theory. Credit facilities (CRD) at first lag have negative impact on consumption in the long run. Specifically, one naira increase in credit facilities at previous values will reduce consumption level by 0.545 . This result is inconsistent with the theoretical postulates which stated that increase in credit facilities will increase consumption through increase in income occasioned by increase in investment.

Inflation rate coefficient is -4.961 suggesting that a one unit increase in inflation will reduce consumption level by 4.96 levels. The implication of this result is that consumers will tend to consume more when the general price level falls that when it rises. This is in line with theory as people's real income will be badly (negatively) affected during inflation and hence a decrease in consumption level. This result corroborates the findings of Kandil and Mirzaie [22]. The coefficient of interest rate is 32.88 suggesting that increase in interest rate will lead to increase in consumption. This results in inconsistent with economic theory.

The result of diagnostic test (table 5) shows that; there is no serial autocorrelation of any order in the model as indicated by the Breusch-Godfrey LM test for 
autocorrelation; the White Heteroskedasticity test shows equal variance in the model; the result of Jarque-Bera equally shows that the residual follows normal distributed and the Ramsey reset test indicated no evidence of omitted variable in the model specified.

\section{Conclusion and Policy Implication}

The study investigated the long run determinants of consumption spending in Nigeria using ARDL bound cointegration test. The empirical results showed that in the short run, disposable income, financial assets, interest rate and government expenditure influence consumption spending while disposable income, financial assets, credit facilities and government expenditures are the major longrundeterminants of consumption spending in Nigeria. The result equally showed that disposable income has more impact on consumption spending in the long run than it has in the short run. The policy implication of the result is that policy interventions directed towards these variables are essential to increase spending as a major component of aggregate demand. Also, government expenditure in key productive sector of the economy is necessary as to increase aggregate consumption and ultimately the national income through the multiplier effect. Government should provide enabling environment that will encourage savings and hence increase in financial assets as this will also increase consumption in the long run. Also, economic reforms must target macroeconomic stability, removal of structural distortion and creation of business-friendly environment for enhancing domestic savings capacity and hence investment diversification.

\section{References}

[1] Keynes, J. M. (1936) The general theory of employment interest and money, New York: Harcourt, Bruce and World.

[2] Friedman, M. (1957). A Theory of the Consumption Function, Princeton University Press, Princeton. consumption.

[3] Modigliani, F. \& R. Brumberg (1954). Utility Analysis and the Consumption Function: An Interpretation of Cross-Section Data, In Post-Keynesian Economics, ed. K. Kurhira. New Brunswick, NJ: Rutger University Press.

[4] Gabriela, C. (2007). "The wealth effect on consumption in the Portuguese economy." Economic Bulletin, Banco de Portugal, 2007.

[5] Odionye, J. C., Ugwuegbe, S. U. and Ibeleme, S. N. O (2015). "The effect of financial wealth on private consumption: Evidence from Nigeria." British Journal of Economics, Management and Trade, 6 (4), 300-307.
[6] Ezeji, C. E. and Ajudua, E. I. (2015). "Determinants of aggregate consumption expenditure in Nigeria." Journal of Economics and Sustainable Development, 6 (5), 164-169.

[7] National Bureau of Statistics (2012), Consumption Pattern in Nigeria, 2009/2010, NBS Abuja, Nigeria.

[8] Harmonized Nigeria Living Standard Survey (2010).

[9] World Development Indicators Report (2014).

[10] Ernest S. O. \& Fadiya B. B. (2011) Macroeconomic volatility and private consumption expenditure, implication for household welfare. A dynamic macro-econometric stochastic model. European journal of social sciences 20 (2).

[11] Tsenkwo J. B (2011). Testing Nigeria's marginal propensity to consume (mpc) within the period $1980-2004$, journal of innovative research in management and humanities 2(1) 1525.

[12] Akekere J. and Yousuo P. O. J (2012) Empirical analysis of change in income on private consumption expenditure in Nigeria. International journal of Academic Research in Business and Social Sciences. , 2(11).

[13] Pesaran, M. H and Pesaran, B. (1997), Working with Microfit 4.0: Interactive Econometric Analysis. Oxford, Oxford University Press.

[14] Pasaran M. H, Y. Shin \& R. Smith (2001), Bound Testing Approaches to the Analysis of Level Relationships. Journal of Applied Economics, 16, 289-326.

[15] Banerjee A. (1993), "Co-integration, Error Correction, and the Econometric Analysis of Non-Stationary Data". Oxford, Oxford University Press.

[16] Tang, T. C. (2003). Japanese aggregate import demand function: Reassessment from the 'bound'testing approach. Japan and the World Economy. 15: 419-436.

[17] Shrestha, M. B and Chowdury, K (2007), “Testing Financial Liberalization Hypothesis with ARDL modelling approach, Applied Financial Economics 17: 1529-154.

[18] Central Bank of Nigeria (2015). C. B. N. (2015) Statistical Bulletin.

[19] Bimal S. (2004) Modelling real private consumption expenditure, An empirical study on Fuji.

[20] Sakib- Bin A. (2011). Causal relationship between consumption expenditure and economic growth in Bangladesh”. World journal of social sciences(1) 2,158-169.

[21] Ricardo M. Sousa Wealth effects on consumption: evidence from the Euro areaBanks and Bank Systems. 2010;5(2).

[22] Kandil, M. and A. Mirzaie, (2006) Consumption and macroeconomic policies: Theory and evidence from developing countries, Journal of International Trade and Economic Development, 15, 469-491. 